Short Communication

\title{
Synthesis of $5 \mathrm{~mol} \% \mathrm{Ga}^{3+}$-doped $\mathrm{SnP}_{2} \mathrm{O}_{7} / \mathrm{KPO}_{3}$ composite electrolyte for intermediate temperature fuel cells
}

\author{
Yan Han ${ }^{*}$, Jingjing Zhu, Peng Sun, Nan Wang \\ Anhui Provincial Key Laboratory for Degradation and Monitoring of Pollution of the Environment; \\ School of Chemical and Material Engineering, Fuyang Normal University, Fuyang 236037, China \\ *E-mail: hanyan624000@126.com
}

doi: $10.20964 / 2020.06 .01$

Received: 7 February 2020 / Accepted: 23 March 2020 / Published: 10 May 2020

In this study, $5 \mathrm{~mol} \% \mathrm{Ga}^{3+}$-doped $\mathrm{SnP}_{2} \mathrm{O}_{7} /$ corresponding metaphosphate composite electrolyte was prepared. Synthesis and intermediate temperature electrical properties of $\mathrm{Sn}_{0.95} \mathrm{Ga}_{0.05} \mathrm{P}_{2} \mathrm{O}_{7} / \mathrm{KPO}_{3}$ were investigated. The X-ray diffraction result showed that the composite electrolyte had a pyrophosphate structure. Conductivities of the composite electrolyte indicated that it had a good linear Arrhenius relationship in the whole test temperature range. The highest conductivity of $\mathrm{Sn}_{0.95} \mathrm{Ga}_{0.05} \mathrm{P}_{2} \mathrm{O}_{7} / \mathrm{KPO}_{3}$ was $3.4 \times 10^{-2} \mathrm{~S} \cdot \mathrm{cm}^{-1}$ at $700{ }^{\circ} \mathrm{C}$.

Keywords: Composite; X-ray diffraction; Conductivity; Electrolyte; Fuel cell

\section{$\underline{\text { FULL TEXT }}$}

(C) 2020 The Authors. Published by ESG (www.electrochemsci.org). This article is an open access article distributed under the terms and conditions of the Creative Commons Attribution license (http://creativecommons.org/licenses/by/4.0/). 